\title{
Therapeutic Proposals That Improve Morphological Changes Of 5-Fluorouracil-Induced Intestinal Mucositis: a Review of the Literature
}

\author{
Maria Lucianny Lima Barbosa, ${ }^{1}$ Lorena Lopes Brito, ${ }^{2}$ Bárbara Barbosa Pires, ${ }^{3}$ Joselane Maria da Silva, ${ }^{4}$ João Antônio Leal de \\ Miranda, ${ }^{4}$ Gilberto Santos Cerqueira'
}

${ }^{1}$ Universidade Federal do Ceará, Fortaleza, CE, Brazil

${ }^{2}$ Universidade Estadual do Ceará;, Fortaleza, CE, Brazil

${ }^{3}$ Faculdade de medicina São Lucas, Porto Velho, RO, Brazil

${ }^{4}$ Universidade Federal do Piauí, Teresina, PI, Brazil

Disclose and conflicts of interest: none to be declared by all authors

\begin{abstract}
Introduction: In this study, we aimed to perform a literature review to investigate the existence of therapeutic proposals in 5-Fluoruracil-induced intestinal mucositis, which is a common side effect of chemotherapy treatment. The literature review was performed using PubMed, Science Direct, and Bireme between 2015 and 2019. The descriptors used "intestinal mucositis" AND "intestinal mucositis and 5-Fluorouracil". We excluded from the review studies, double data studies, titles and/or summaries that did not address therapeutic proposals, and articles not available in full. Were selected thirty-two articles, which had the objective of evaluating the effect of substances on the model of intestinal mucositis induced by 5-Fluorouracil; it is emphasized that no articles with clinical evaluation were found. On the other hand, several animal studies are being carried out with the main objective being the evaluation of probiotics, products of natural origin, and drug repurposing for the treatment of intestinal mucositis. The main morphological parameters evaluated were histological changes, inflammatory parameters, oxidative stress, intestinal permeability, microbiota homeostasis, cell apoptosis, and the number of goblet cells that are altered during the pathophysiology of intestinal mucositis. It was verified that there is still no evidence in the literature for the existence of effective clinical treatment for intestinal mucositis induced by 5-Fluorouracil. However, promising preclinical results were found with extracts of traditional plants, substances isolated from plants, and probiotics with emphasis on those of the genus Lactobacillus.

Keywords: Intestinal mucositis; Treatment; Probiotics; Plants; Drugs.
\end{abstract}

\section{Introduction}

Cancer is currently one of the most prevalent diseases worldwide. It is of great epidemiological importance, since its risk factors are highly varied and related to morbidity and mortality. The number of new cases of cancer has increased, and in 2017 there were 24.5 million cancer cases worldwide. Conversely, therapy for this disease includes several complications that depend on tumor location, malignancy, staging, and treatment modality ${ }^{1,2}$.

Surgery, radiation, chemotherapy, targeted treatments, and immunotherapy, separately or in combination, are commonly used to treat cancer. However, chemotherapy can be cited as one of the most used. It is used to eradicate malignant cells and to inhibit or prevent the growth and spread of these cells $^{3}$. 5-Fluorouracil (5-FU) is a chemotherapeutic agent, and of its main side effects mucositis is the most common ${ }^{4.5}$.

Mucositis is a resultant complex condition of inflammation of the oral or intestinal mucosa by the action of chemotherapeutic drugs or ionizing radiation, and it is one of the most significant side effects in the treatment of cancers. It is known as oral mucositis or intestinal mucositis, depending on the inflammation $\operatorname{area}^{6,7}$

Intestinal mucositis results in villous atrophy, ulceration, and loss of intestinal barrier function. Mucositis can also lead intestinal basal substances to apoptosis due to their toxicity to intestinal tissue cell renewal. This biological mechanism makes patients suffer from nausea, vomiting, diarrhea, pain, weight loss, and need for enteral or parenteral nutrition. It may also lead to malnutrition and electrolyte imbalance, resulting in an increased risk of sepsis and death ${ }^{8,9,10,11}$.

Effective therapy for this clinical condition does not yet exist, so prevention and control of mucositis symptoms are of paramount importance to avoid reducing the patient's motivation to proceed with the treatment plan and possibly compromise local control of the mucositis tumor and decrease survival rates ${ }^{8,12}$.

Thus, the present work intends to investigate the state of the art regarding the therapeutic proposals for 5-FU-induced intestinal mucositis, through a literature review. 


\section{Materials and Methods}

In this review, we searched for articles indexed in PubMed, ScienceDirect, and Bireme electronic databases, published in English, from 2015 to 2021. The review was restricted to articles that address therapeutic proposals for 5-FU-induced intestinal mucositis.

Articles were searched from January to March 2021. Access to federated communities was made available through the CAPES journal portal to obtain the full articles. The descriptors used were: "intestinal mucositis", "intestinal mucositis AND 5-Fluorouracil" and "intestinal mucositis AND 5-fluorouracil AND treatment", and 5390 articles were found. Review studies, the duplication of data or titles, abstracts that did not meet the inclusion criteria and lack of pertinent information were all excluded, totaling 32 articles for analysis in this review.

For the discussion of the data and interpretation of theresearch, the approach to the theme was considered; the year of publication; the article available in full. The presentation of the articles found, both included and excluded, as well as their applied distribution, is shown in the PRISMA flow (Figure 1).

\section{Results and Discussion}

By searching the databases cited, the search found 5390 studies in the period, but 5358 were rejected, as they did not meet the inclusion criteria. Thus, a total of 32 publications were selected on the subject, covering the treatment of 5-FU-induced intestinal mucositis in the period highlighted in this study (Table 01), which were accessed and read for subsequent selection of the characteristics that incorporated the research.

Regarding intestinal mucositis, this review showed there is no effective clinical treatment for this condition, since no articles were found pointing to clinical evidence. On the other hand, several types of animal research are being developed, which generally evaluate the effectiveness of a certain substance, based on the discovery of the pharmacological effect of these substances on the fundamental mechanisms involved in the pathogenesis of mucositis, such as the generation of reactive oxygen species (ROS), proinflammatory cytokines, mediators of apoptosis, microbiota alteration and damage and rupture of the epithelial barrier.
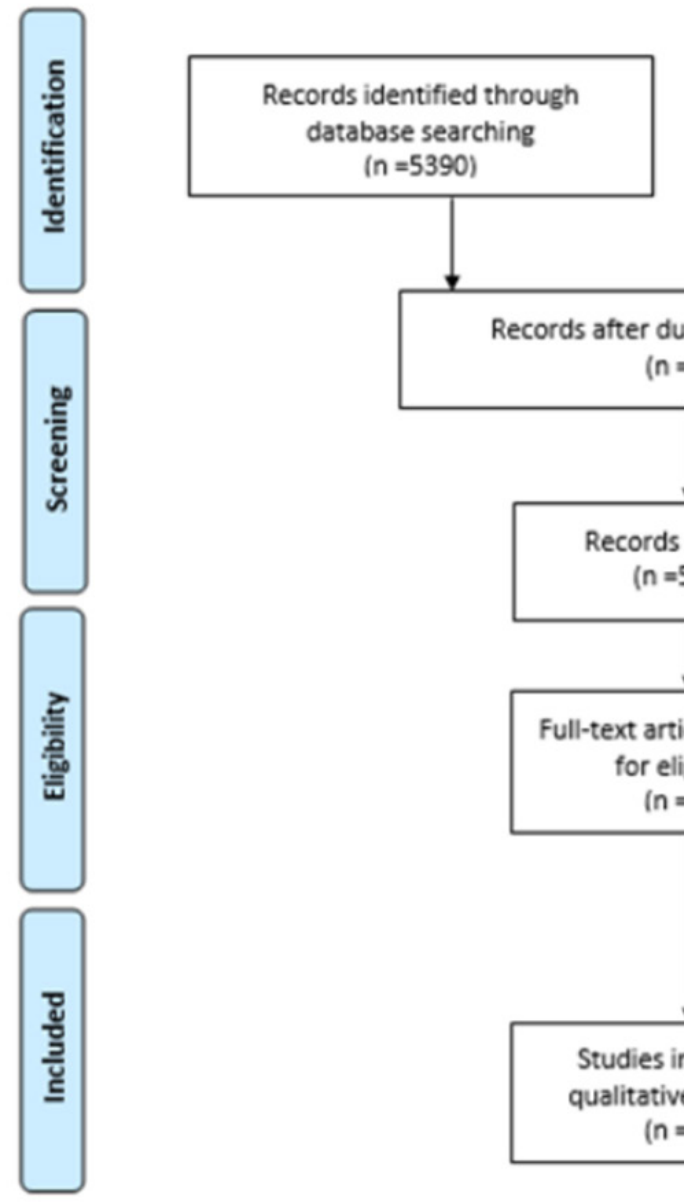

Additional records identified through other sources $(n=0)$
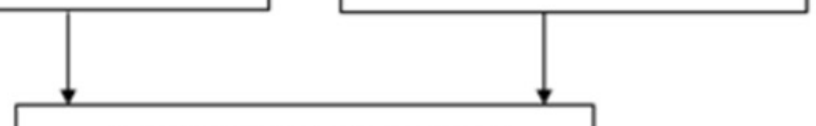

Records after duplicates removed $(n=29)$

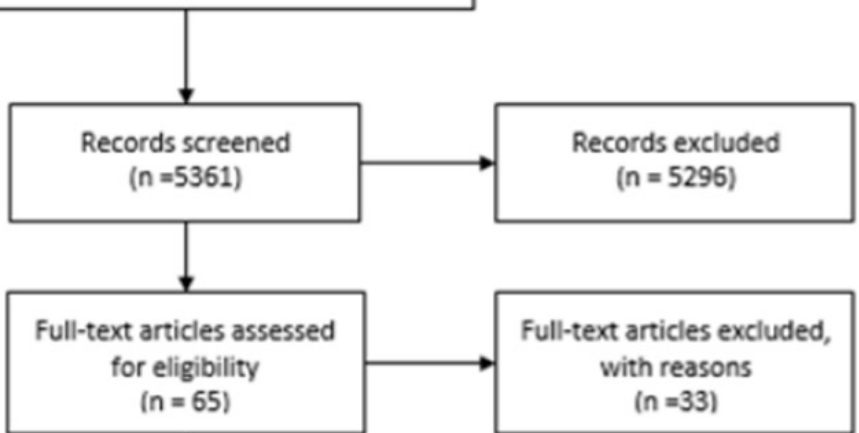

Studies included in

qualitative synthesis

$(n=32)$ 
Table 1. Main aspects of studies on intestinal mucositis, in chronological order, in articles published from 2015 to 2019.

\begin{tabular}{|c|c|c|c|c|c|}
\hline № & Type of study & Periodical & $\begin{array}{c}\text { Place of } \\
\text { study }\end{array}$ & Main aspects & References \\
\hline 1 & Experimental & PlosOne & Taipei & $\begin{array}{l}\text { Lactobacillus caseivariety rhamnosus (Lcr35) } \\
\text { and Bifidobacterium bifidum (LaBi) probiotics } \\
\text { may improve chemotherapy-induced } \\
\text { intestinal mucositis. }\end{array}$ & $\begin{array}{l}\text { Yeung et al., } \\
2015^{13}\end{array}$ \\
\hline 2 & Experimental & Plos One & Kyoto & $\begin{array}{l}\text { Saireto, a traditional Japanese herbal } \\
\text { medicine, attenuates intestinal mucositis } \\
\text { induced by 5-FU. }\end{array}$ & $\begin{array}{l}\text { Kato et al., } \\
2015^{14}\end{array}$ \\
\hline 3 & Experimental & Biol. Pharm. Bull. & Gyeonggi-Do & $\begin{array}{l}\text { Rebamipid promotes various mechanisms of } \\
\text { mucosal protection and attenuates mucosal } \\
\text { lesion induced by } 5-\mathrm{FU} \text {. }\end{array}$ & $\begin{array}{l}\text { Kim et al., } \\
2015^{10}\end{array}$ \\
\hline 4 & Experimental & Tox. reports & Goiania & $\begin{array}{l}\text { The results showed Mucoadhesive } \\
\text { formulation of Bidens pilosa } \mathrm{L} \text {. to be safe } \\
\text { and efficient against 5-FU induced intestinal } \\
\text { mucositis in mice. }\end{array}$ & $\begin{array}{l}\text { DE ÁVILA et } \\
\text { al., } 2015^{9}\end{array}$ \\
\hline 5 & Experimental & Lipids Health Dis & $\begin{array}{l}\text { Belo } \\
\text { Horizonte }\end{array}$ & $\begin{array}{l}\text { Dietary supplementation with omega-3 fatty } \\
\text { acid decreases the mucosal damage caused } \\
\text { by } 5 \text {-FU-induced mucositis. }\end{array}$ & $\begin{array}{l}\text { GENEROSO et } \\
\text { al., } 2015^{16}\end{array}$ \\
\hline 6 & Experimental & Hum ExpToxicol; & Shenyang & $\begin{array}{l}\text { Bu-Zhong-Yi-Qi decoction (BZYQD) inhibits } \\
5 \text {-FU-induced intestinal mucositis, and } \\
\text { this effect may be due to the reductionin } \\
\text { apoptosis and necrosis in intestinalmucosal } \\
\text { epithelia via the suppression of inflammatory } \\
\text { cytokine upregulation. }\end{array}$ & $\begin{array}{l}\text { GOU et al., } \\
2016[17]\end{array}$ \\
\hline 7 & Experimental & $\begin{array}{l}\text { Eur Revfor Med and } \\
\text { Pharma Scien }\end{array}$ & Cluj-Napoca & $\begin{array}{l}\text { Pretreatment with rifaximin for three } \\
\text { consecutive days proved efficient in } \\
\text { preventing degenerative mucosal lesions } \\
\text { induced by 5-FU in the duodenum, jejunum } \\
\text { and colon. }\end{array}$ & $\begin{array}{l}\text { Ciobanu etal., } \\
2016^{5}\end{array}$ \\
\hline 8 & Experimental & World Jour Gastroent & Adelaide & $\begin{array}{l}\text { Low dose rhubarb extract improves selected } \\
\text { parameters of mucosal integrity and reduces } \\
\text { ileal inflammation, manifesting from 5-FU- } \\
\text { induced intestinal mucositis. }\end{array}$ & $\begin{array}{l}\text { Bajic et al., } \\
2016^{2}\end{array}$ \\
\hline 9 & Experimental & Toxicology Reports & Goiânia & $\begin{array}{l}\text { Curcuminoid mucoadhesive formulation } \\
\text { (MFC) from Curcuma longa L. presented } \\
\text { therapeutic potential for the treatment of } \\
\text { intestinal mucositis in mice. }\end{array}$ & $\begin{array}{l}\text { Dos Santos } \\
\text { Filho et al., } \\
2016^{18}\end{array}$ \\
\hline 10 & Experimental & $\begin{array}{l}\text { Journal of } \\
\text { Ethnopharmacology }\end{array}$ & Beijing & $\begin{array}{l}\text { Wei-Chang-An, a traditional Chinese } \\
\text { pharmaceutical preparation promoted the } \\
\text { restoration of intestinal function in 5-FU- } \\
\text { induced intestinal mucositis. }\end{array}$ & $\begin{array}{l}\text { Chen et al } \\
2016^{6}\end{array}$ \\
\hline 11 & Experimental & Toxicology Reports & Goiânia & $\begin{array}{l}\text { A mucoadhesive formulation containing } \\
\text { Bidens pilosa } \mathrm{L} \text {. and Curcuma longa } \mathrm{L} \text {. was } \\
\text { able to protect mice from 5-FU-induced } \\
\text { intestinal injury. }\end{array}$ & $\begin{array}{l}\text { Bastos et al., } \\
2015^{19}\end{array}$ \\
\hline 12 & Experimental & Jour Funct Foods & Hamamatsu & $\begin{array}{l}\text { Arabinoxylan supplementation effectively } \\
\text { improved intestinal mucositis and } \\
\text { myelosuppression. }\end{array}$ & $\begin{array}{l}\text { Song et al., } \\
2016^{20}\end{array}$ \\
\hline 13 & Experimental & $\begin{array}{l}\text { Clin and Exp Pharmac } \\
\text { and Phy }\end{array}$ & Kyoto & $\begin{array}{l}\text { Probiotic Bifidobacterium bifidum G9- } 1 \\
\text { attenuates 5- fluorouracil- inducedintestinal } \\
\text { mucositis in mice via suppression of } \\
\text { dysbiosis- related secondary inflammatory } \\
\text { responses }\end{array}$ & $\begin{array}{l}\text { Kato et al., } \\
2017^{21}\end{array}$ \\
\hline
\end{tabular}




\begin{tabular}{|c|c|c|c|c|c|}
\hline 14 & Experimental & $\begin{array}{l}\text { Journal of physiology } \\
\text { and pharmac }\end{array}$ & Kyoto & $\begin{array}{l}\text { Lafutidine, a histamine } \mathrm{H} 2 \text { receptor } \\
\text { antagonist, can attenuate } 5 \text {-FU-induced } \\
\text { intestinal mucositis, most likely byincreasing } \\
\text { mucus production via activation of sensory } \\
\text { afferent neurons. }\end{array}$ & $\begin{array}{l}\text { Sano et al., } \\
2017^{22}\end{array}$ \\
\hline 15 & Experimental & Front Pharmacol & Kunming & $\begin{array}{l}\text { Amomum villosum (VOA) and its main active } \\
\text { constituent, bornyl acetate (BA), attenuates } \\
\text { 5- fluorouracil-inducedintestinal mucositis } \\
\text { in mice. }\end{array}$ & $\begin{array}{l}\text { Zhang et al., } \\
2017^{23}\end{array}$ \\
\hline 16 & Experimental & Nutrition & Dalian & $\begin{array}{l}\text { Treatment with a probiotic mixture, } \\
\text { (Bifidobacterium breve, Lactobacillus } \\
\text { acidophilus, L. casei and Streptococcus } \\
\text { thermophilus) ameliorated 5-FU-induced } \\
\text { intestinalmucositis. }\end{array}$ & $\begin{array}{l}\text { Tang et al., } \\
2017^{24}\end{array}$ \\
\hline 17 & Experimental & $\begin{array}{l}\text { Letters in Applied } \\
\text { Microbiology }\end{array}$ & Seoul & $\begin{array}{l}\text { Mulberry leaf extract fermented with } \\
\text { Lactobacillus acidophilus A4 ameliorates } \\
\text { 5- fluorouracil- induced intestinal mucositis } \\
\text { in rats. }\end{array}$ & $\begin{array}{l}\mathrm{OH} \text { et al., } \\
2017^{24}\end{array}$ \\
\hline 18 & Experimental & Nutrition & Tucumán & $\begin{array}{l}\text { The riboflavin-overproducing strain } \\
\text { Lactobacillus plantarum CRL } 2130 \text { could be } \\
\text { useful to prevent mucositis during cancer } \\
\text { treatments and would not affect the primary } \\
\text { treatment. }\end{array}$ & $\begin{array}{l}\text { Levit et al., } \\
2018^{26}\end{array}$ \\
\hline 19 & Experimental & Rev Col Bras Cir & Natal & $\begin{array}{l}\text { Simvastatin attenuated gastric and intestinal } \\
\text { mucositis related to 5-FU therapeutics in } \\
\text { animal model }\end{array}$ & $\begin{array}{l}\text { Medeiros et } \\
\text { al., } 2018^{27}\end{array}$ \\
\hline 20 & Experimental & $\begin{array}{l}\text { JournaL ofFunctional } \\
\text { Foods }\end{array}$ & $\begin{array}{l}\text { Belo } \\
\text { Horizonte }\end{array}$ & $\begin{array}{l}\text { The results showed fruit oligosaccharide } \\
\text { (FOS) supplementation presented protective } \\
\text { effectson intestinal barrier function. }\end{array}$ & $\begin{array}{l}\text { Galdino et } \\
\text { al., } 2018^{28}\end{array}$ \\
\hline 21 & Experimental & Front Microbiol & $\begin{array}{l}\text { Belo } \\
\text { Horizonte }\end{array}$ & $\begin{array}{l}\text { Whey Protein Isolate-Supplemented } \\
\text { maximizes the anti-inflammatory effects } \\
\text { of Lactobacillus casei BL23, in preventing } \\
\text { mucositis induced by 5-Fluorouracil in BALB/C } \\
\text { mice. }\end{array}$ & $\begin{array}{l}\text { Cordeiro et } \\
\text { al., } 2018^{7}\end{array}$ \\
\hline 22 & Experimental & Journal of MedFood & Guangzhou & $\begin{array}{l}\text { Enteral Nutrition Supplemented with } \\
\text { Crassostrea hongkongensis Polysaccharides } \\
\text { can ameliorate 5-FU-induced intestinal } \\
\text { mucositis. }\end{array}$ & $\begin{array}{l}\text { CAl et al., } \\
2018^{4}\end{array}$ \\
\hline 23 & Experimental & Phytomedicine & Tianjin & $\begin{array}{l}\text { Aquilariae Lignum Resinatum protected } \\
\text { against 5-FU-induced intestinal mucositis in } \\
\text { mices. }\end{array}$ & $\begin{array}{l}\text { Zheng et al., } \\
2019^{29}\end{array}$ \\
\hline 24 & Experimental & $\begin{array}{l}\text { Journal of Functional } \\
\text { Foods }\end{array}$ & $\begin{array}{l}\text { Belo } \\
\text { Horizonte }\end{array}$ & $\begin{array}{l}\text { The work demonstrates the protective effect } \\
\text { of Lactobacillus delbrueckii subsp. lactis } \\
\text { CIDCA } 133 \text { on the damage of the intestinal } \\
\text { mucosa in a murine model of inflammation } \\
\text { induced by a chemotherapeutic drug. }\end{array}$ & $\begin{array}{l}\text { De Jesus et } \\
\text { al., } 2019^{10}\end{array}$ \\
\hline 25 & Experimental & Eurjour of Pharmac & Islamabad & $\begin{array}{l}\text { Diadzein could inhibit 5-FU-induced } \\
\text { intestinal mucositis. }\end{array}$ & $\begin{array}{l}\text { Atiq et al., } \\
2019^{1}\end{array}$ \\
\hline 26 & Experimental & Phamaceuticals & Fortaleza & $\begin{array}{l}\text { Cashew Gum (Anacardium occidentale L.) } \\
\text { prevented 5-FU-induced intestinal mucositis. }\end{array}$ & $\begin{array}{l}\text { De Mirandaet } \\
\text { al., } 2019^{11}\end{array}$ \\
\hline 27 & Experimental & Food \& Function & Beijing & $\begin{array}{l}\text { Carboxymethyl pachyman could regulate the } \\
\text { ecological balance of the intestinal flora and } \\
\text { reduce colon injuries induced by 5-FU in CT26 } \\
\text { tumour-bearing mice }\end{array}$ & $\begin{array}{l}\text { Wang et al., } \\
2018^{30}\end{array}$ \\
\hline
\end{tabular}




\begin{tabular}{|c|c|c|c|c|c|}
\hline 28 & Experimental & $\begin{array}{l}\text { Pediatrics and } \\
\text { Neonato }\end{array}$ & Taipei & $\begin{array}{l}\text { Probiotics Lactobacillus casei variety } \\
\text { rhamnosus or Lactobacillus acidophilus } \\
\text { and Bifidobacterium bifidum do not lead to } \\
\text { bacteremia, and had beneficial effects on } \\
\text { mucositis. }\end{array}$ & $\begin{array}{l}\text { Huang et al., } \\
2019^{31}\end{array}$ \\
\hline 29 & Experimental & Molecules & Fortaleza & $\begin{array}{l}\text { Rutin attenuated the inflammatory response } \\
\text { in intestinal mucositis. }\end{array}$ & $\begin{array}{l}\text { Fidelis et al, } \\
2020^{32}\end{array}$ \\
\hline 30 & Experimental & Life Sciences & Wuhan & $\begin{array}{l}\text { Andrographolide ameliorated 5-FU induced } \\
\text { intestinal mucositis. The apoptosis of } \\
\text { intestinal cells was also attenuated by } \\
\text { treatment. }\end{array}$ & $\begin{array}{l}\text { Xiang et al., } \\
2020^{33}\end{array}$ \\
\hline 31 & Experimental & Biomed \& Phamac & Zhejiang & $\begin{array}{l}\text { Berberine repaired disrupted gut microbiota, } \\
\text { reducing the inflammatory response and } \\
\text { protecting the intestinal mucosa. }\end{array}$ & $\begin{array}{l}\text { Chen et al., } \\
2020^{34}\end{array}$ \\
\hline 32 & Experimental & Biomed \& Pharma & $\begin{array}{l}\text { Belo } \\
\text { Horizonte }\end{array}$ & $\begin{array}{l}\text { Pretreatment and total treatment with FOS } \\
\text { in mucositis induced by } 5 \text {-FU had beneficial } \\
\text { effects on mouses. }\end{array}$ & $\begin{array}{l}\text { Carvalho et } \\
\text { al., } 2021^{35}\end{array}$ \\
\hline
\end{tabular}

The articles presented in this review bring into their methodological scope the evaluation of products of natural origin, nutritional supplementation/ probiotics or drugs that are redirected to the treatment of intestinal mucositis.

Probiotics and Nutritional Supplements

We found 12 articles evaluating the effect of probiotics and other nutritional supplements on intestinal mucositis (IM) induced by 5-FU. The articles found in this review separately evaluated four types of probiotics, namely: Lactobacillus delbrueckii ${ }^{10}$, Lactobacillus casei variety rhamnosus, Bifidobacterium bifidum $^{13,14,21}$, and Lactobacillus plantarum ${ }^{26}$. In addition to the combination of L. casei BL2, and/ or Propionibacterium freudenreichii $138+$ Whey Protein isolate ${ }^{7}$, as well as a mixture of probiotics from four strains (Bifidobacterium breve, Lactobacillus acidophilus, L. casei e Streptococcus thermophilus) ${ }^{24}$, and the combination of mulberry leaf extract with Lactobacillus acidophilus ${ }^{25}$.

The study of De Jesus et al..$^{10}$ demonstrated that milk fermented with L. delbrueckii was able to prevent weight loss, and leukopenia, in addition to preserving villus/crypt ratio, decreasing small intestine permeability, reducing goblet cell loss, and intestinal secretion of IgA. The authors also showed this strain reduced the inflammatory secretion of neutrophils and eosinophils (MPO and EPO) in ileum sections of 5-FU treated animals.

The treatment with Bifidobacterium G9-1(BBG9-1), was ably attenuated the inflammatory marked myeloperoxidase (MPO) activity, TNF- $\alpha$, and IL- $1 \beta$, the shortening of villi, and the decrease in the number of cells in the crypts. In contrast, BBG9- 1 failed to prevent apoptosis induction. The authors suggest the ameliorative effect against 5-FU-induced intestinal mucositis through the attenuation of inflammatory responses via improving dysbiosis ${ }^{20}$.
Levit et al. ${ }^{26}$ demonstrated that L. Plantarum CRL2130 attenuated the pathologic changes induced by 5 -FU in mice such as body weight loss, diarrhea, shortening of villus height, and elevated production of interleukin 10, an anti-inflammatory cytokine. In vitro assays using Caco-2 cells showed the effectiveness of 5-FU was not affected by L. Plantarum CRL2130 and that this strain exerted an inhibitory mechanism against oxidative stress.

Other researchers showed the mulberry leaf extract fermented with Lactobacillus acidophilus A4 has ably ameliorated the weight loss and the histopathologic parameters. The treatments also stimulated MUC2 and MUC5AC gene expression and mucin production and reduced IL- $1 \beta$ expression and MPO level. These results suggest fermented mulberry leaf extract may provide synergistic therapeutic benefits of both probiotics and natural plant extracts in the prevention of 5- fluorouracil-induced mucositis ${ }^{25}$.

Yeung and collaborators ${ }^{13}$ found after oral Lactobacillus acidophilus and Bifidobacterium bifidum administrations, the diarrhea scores decreased, repairing of damage in jejunal villi was observed and the probiotics treatment suppressed this upregulation the TNF- $\alpha$, IL-1 $\beta$, and IL- 6 . Huang et al. ${ }^{31}$ also demonstrated that Lactobacillus casei variety rhamnosus or the mixture that Lactobacillus acidophilus and Bifidobacterium bifidum could significantly inhibit serum cytokines TNF-a, IL- $1 \beta$, IFNg, IL-6, IL-4, IL10 , and IL-17, and that it could improve diarrhea with jejunal mucosa repair.

In the study by Cordeiro et al. ${ }^{7}$, it was observed probiotic beverages fermented by L. casei BL23 and P. freudenreich 138 were able to decrease 5-FU-induced intestinal inflammation, preserving mucosal integrity, and reducing weight loss and preserving the number. of goblet cells. The addition of Whey Protein-Isolate was found to improve the beneficial effects of L. casei 
BL23, but not P. freudenreichii.

The treatment with a probiotic mixture (Bifidobacterium breve, Lactobacillus acidophilus, L. casei e Streptococcus thermophilus) ameliorated 5-FU-induced intestinal mucosal injury, preserved histopathological changes, and mucus reduced the proinflammatory cytokines (IL-4, IL-6, TNF- $\alpha$ ) and neutrophil infiltration, but not reduced the bodyweight loss. Moreover, the treatment reduced the intestinal permeability and reestablishment of intestinal microbial homeostasis and alteration of the toll-like receptors 2 and 4 (TLR2/TLR4) signaling pathway a defense system against microorganisms ${ }^{24}$.

The exact mechanisms by which probiotics exert their beneficial effects remain unknown. However, from the findings in this review, it was observed probiotics appear to attenuate the severity of mouseinduced intestinal mucositis by $5-\mathrm{FU}$ treatment by inhibiting inflammatory parameters (cytokines and neutrophils), improving intestinal permeability and microbiota balance.

According to Van et al. ${ }^{36}$, the microbiota can influence mucositis development and severity through at least five different mechanisms. These include influencing the inflammatory response, intestinal permeability, mucin layer composition, epithelial repair, resistance to harmful stimuli, and the intestinal immune system, all of which can have important implications for both mucositis severity and host health.

Prebiotics is nondigestible food ingredients that selectively stimulate the growth or activity of bacteria in the colon, that beneficially affect the host. In this sense, Galdino et al. ${ }^{28}$ demonstrated that fructooligosaccharides (prebiotic) were also capable of reduced inflammatory infiltrate (MPO) and improved intestinal permeability, and preserved intestinal mucosa. Carvalho et al. ${ }^{35}$ also found that fructooligosaccharides effects included maintenance of tight junctions expression with a reduction in the inflammatory infiltrate and histological score and improvement in short-chain fatty acids production. These effects contributed to the restoration and preservation of mucosal architecture.

In turn, Generoso et al. ${ }^{16}$ showed omega-3 supplementation less weight loss decreased intestinal permeability and bacterial translocation besides preserving the mucosal integrity and reduced number of apoptotic cells the ileum mucosa. Cai et $\mathrm{al}^{4}$ also observed the enteral nutrition supplemented with Crassostrea hongkongensis Polysaccharides showed to positively influence in intestinal mucositis, since, ameliorate atrophy of the villi with fewer goblet cells, reducing pro-inflammatory cytokine secretion (IL2), releasing anti-inflammatory cytokines (IL-10), inhibiting inflammatory pathways, improving the barrier function, preventing epithelial cell apoptosis and eliminating pathogenic bacteria.

In summary, Table 2 shows the synthesis of effective probiotics and supplements in the studies.

\section{Plant extracts and substances isolated}

We found 16 articles in which the authors investigated the protective effect of products of natural origin, plant extracts, or even plant-isolated substances. A common feature of this group is that the investigated substances had a traditional use and/or already had evidence of antioxidant and anti-inflammatory activity $9,11,12,14,18$. The main parameters included histological evaluation, body weight, inflammatory and oxidative parameter evaluation, apoptosis evaluation, and investigation of the probable way in which the substances acted.

Atiq et al. ${ }^{1}$ demonstrated that diadzein, an isoflavone in nature and isolated from plants such as soybean, was able to inhibit 5-FU-induced intestinal mucositis. It did this by preventing leukopenia, decreasing morphometric and histopathological changes, inhibiting oxidative stress with the equilibrium of GSH, GTS, MDA, catalase and nitrite concentrations, as well as the preservation of goblet cells' equilibrium in the inflammatory parameters (COX-2, TNF- $\alpha$, p-JNK, IL-6 , IL-1 $1 \beta$ ).

Table 2. Concentration of probiotics and supplements used in preclinical studies for intestinal mucositis induced for 5-Fluorouraci

\begin{tabular}{l|l}
\hline \multicolumn{1}{c|}{ Probiotic/ Nutritional supplement } & \multicolumn{1}{c}{ Concentration } \\
\hline L. delbrueckii subsp. lactis CIDCA 133 fermented milk & $7.5 \times 10^{7} \mathrm{CFU} / \mathrm{ml}$ \\
\hline Mulberry leaf extract fermented with L. acidophilus A4 & $100 \mu \mathrm{g} / \mathrm{ml}$ and $10^{9} \mathrm{CFU} / \mathrm{ml}(\mathrm{A} 4)$ \\
\hline L. plantarum & $10^{8} \mathrm{CFU} / \mathrm{ml}$ \\
\hline L.casei and P. freudenreichii 138 with Whey Protein & $10^{9} \mathrm{CFU} / \mathrm{ml}$ \\
\hline Probiotic mixture (B. breve, L. acidophilus, L. casei, and S. thermophilus). & $10^{9} \mathrm{CFU}$ \\
\hline L. casei variety rhamnosus and L.acidophilus with B. bifidum & $10^{7} \mathrm{CFU}$ \\
\hline B. bifidum & $10^{9} \mathrm{CFU}$ \\
\hline Fructo-oligosaccharides & $240 \mathrm{mg}(6 \%$ of total $\mathrm{kg})$ \\
\hline Crassostrea hongkongensis Polysaccharides & $0,0195 \mathrm{mg} / \mathrm{mL}$ \\
\hline Dietary supplementation with omega-3 fatty acid & $3.5 \%$ fish oil \\
\hline
\end{tabular}


Miranda et al. ${ }^{11}$ showed that Cashew Gum (a polysaccharide) was able to reverse weight loss, prevent histopathological changes, decrease the number of mast cells, and reduce leukopenia. Moreover, Cashew Gum also reduced oxidative stress, the expression of COX-2 and IL- $1 \beta$, and the concentration of MPO.

Bu-Zhong-Yi-Qi's decoction (BZYQD), a water extract of Chinese traditional herbal medicine, was able to inhibit morphological signs of intestinal damage, including shortened villi height. Crypt destruction, apoptosis, and necrosis in intestinal mucosal epithelia were also reversed, accompanied by reduced neutrophil infiltration, nitrite levels, and inflammatory factors (TNFa and IL1ß) and increased levels of reduced glutathione ${ }^{17}$.

Aquilariae Lignum Resinatum, also a traditional Chinese medicine treatment, improved food-intake and reduced injury of the intestinal mucosa, relieved body weight loss and severe diarrhea through up-regulating the expression of proliferating cell nuclear antigen (PCNA) and inhibiting the levels of cyclooxygenase-2 $(\mathrm{COX}-2)$ and tumor necrosis factor- $\alpha(\mathrm{TNF}-\alpha)$ in ileum segments ${ }^{29}$.

Kato et al. ${ }^{14}$, found Saireito, a Japanese traditional herbal medicine, reduced the increase in apoptotic cells on the intestinal crypts, such as the expression of TNF- $\alpha$ and IL- $1 \beta$ mRNA, body weight loss, diarrhea, and potentially reduced tumor growth. In contrast, the administration of Saireto did not alter the antiproliferative action of 5-FU in the intestinal crypts.

A mucoadhesive containing curcuminoids from Curcuma longa L. showed significant results towards body weight loss, as all the animals treated had body weight loss reduced. Besides that, curcuminoids demonstrated a protective effect on 5-FU-induced intestinal mucositis, not only by reducing the shortening in the duodenal villi height and crypt depth but also by decreasing histological severity scores. Besides, there was less apoptosis on intestinal cells, greater expression of Ki-67, and significantly diminished tissue oxidative stress and free radical production ${ }^{9}$.

De Ávila et al. ${ }^{9}$ also used a mucoadhesive to treat 5-FU induced mucositis, made of Bidens pilosa $\mathrm{L}$. (Asteraceae). Most of the elements investigated, such as body weight, morphometric and histological analysis, the evaluation of the small intestine, and expression of Ki-67, Bax, MPO, and MDA, had significant results in the groups treated compared with the 5-FU group. Another study investigated the effect of a mucoadhesive containing not only Bidens Pilosa L. (Asteraceae) but also Curcuma longa L. (Zingiberaceae). It protected against 5-FU intestinal damage regarding the size of the crypts and villi and weight loss, promoted the increase of blood cells, and recovered the proliferative activity of the intestinal tissue in the animals with mucositis, due to the significant expression of Ki-67, $\mathrm{Bax}$, and $\mathrm{Bcl}-2^{19}$.
Bajic et al. ${ }^{2}$ showed rhubarb, Rheum spp, a perennial herbaceous plant with anthraquinones as its main active ingredient, in the form of a relatively lowdose aqueous extract, offers partial protection to the distal intestinal mucosa against tissue damage and inflammation associated with 5-FU induced intestinal mucositis.

Wei-Chang-An is a traditional Chinese pharmaceutical preparation with potential antiinflammatory action that reduced body weight loss, alleviating severe diarrhea and gastric emptying (GE), and gastrointestinal transit. Further evaluations also validated that Wei-Chang-An promoted intestinal mucosal recovery, evaluated enterocyte proliferation activity, maintained tight junction integrity, and improved inflammatory disorders ${ }^{6}$.

Song et al. ${ }^{20}$ demonstrated that Arabinoxylan has immunomodulatory effects through activation of NK cells, dendritic cells, modulating cytokines and tumor cell-induced apoptosis, and suppressed the side effects associated with $5-\mathrm{FU}$ in mice, alleviating oxidative stress and myelosuppression.

Xiang et al..$^{33}$ found that Andrographolide, a labdane diterpenoid, significantly ameliorated 5-FU-induced weight loss, diarrhea, and apoptosis. Besides, Andro markedly downregulated the 5-FU-induced protein expression of caspase $8 / 3$, Bax, and the phosphorylation of p38.

Rutin, a flavonoid, prevents intestinal inflammation by inhibiting MDA, MPO, COX-2, oxidative stress and mastocytosis. This flavonoid also stimulates increased villi and increased the GSH concentrations ${ }^{32}$. The authors propose that the action mechanism is the inhibition of COX-2. This hypothesis agrees with Miranda et $a l . .^{12}$, in a study that demonstrated that troxerutin, a flavonoid derived from rutin, also reduced the effects of intestinal mucositis for reduction of COX-2.

Zhang et al..$^{23}$ demonstrated that volatile oil of A. villosum and bornyl acetate prevented diarrhea, reversed weight loss, and reduced food intake. Besides, it improved histopathological changes in intestinal mucositis, perhaps due to a reduction in inflammatory parameters, decreased p38 MAPK and caspase-3 proteins, and improved the function of the intestinal mucosal barrier. Bornyl acetate also contributed to the regulation of intestinal microbiota balance.

Interestingly, Chen et al. ${ }^{34}$ demonstrated that the likely mechanism by which Berberine (isoquinoline alkaloid) would exert its protective effect on intestinal mucositis would be through the regulation of the intestinal microbiota. Wang et al..$^{30}$ also demonstrated that this mechanism is important for intestinal mucositis. The authors found that Carboxymethyl pachyman (a polysaccharide) could regulate the ecological balance of the intestinal flora and reduce colon injuries induced by 5-FU.

In this article, we observed that the researchers 
mainly investigated a wide variety of plants of traditional use, as well as polysaccharides and flavonoids with antioxidant and anti-inflammatory action.

\section{Drug Repurposing}

In this review, we also found 4 papers that evaluated the effect of drugs that were originally recommended for other pathologies, but which have been suggested as an alternative for the treatment of 5-FU-induced intestinal mucositis. Medeiros et al. ${ }^{27}$ investigated the effect of simvastatin, a drug used to treat high cholesterol.

The authors found simvastatin reduced weight loss, improved histopathological scores, and decreased expression of proinflammatory cytokines (TNF- $\alpha$, IL$1 \AA$, and IL-6). The authors did not investigate the likely mechanism of action related to improvement observed with drug use; however, the study suggests that a likely action in COX-2 could explain the decrease in cytokines.

Another study found that Lafutidine, an antiacid histamine H2 receptor antagonist with mucosal protective properties via sensory afferent neurons showed protective effects in intestinal mucositisinduced 5-FU. Lafutidine was able to reduce diarrhea, histopathological changes, MPO, TNF- $\alpha$, IL-1 $\beta$, and apoptosis, but did not decrease weight loss. However, it is worth noting that Lafutidine increased mucus production (number of goblet cells) via activation of sensory afferent neurons ${ }^{22}$.

Kim et $a l . .^{15}$ demonstrated that rebamipide, an anti-gastric ulcer and gastritis agent, showed clinical and histological mucosal protective effects and also preventative effects against apoptosis. It decreased inflammatory cytokines (TGF- $\beta 1$, TNF- $\alpha$ ) and macrophage accumulation, preserved the concentration of GSH, and suppressed iNOS expression and diarrhea.

In an experimental study, Ciobanu et al. ${ }^{5}$ proposed a different approach for microbiota modulation, by using rifaximin, an antibiotic. Rifaximin reduced histopatological scores, preserved goblet cell number, and decreased the expression of TLR. The authors explained that the gut microbiota plays a key role in this phase, through the activation of TRL, and then can also up-regulate NFkB.

Thus, we can observe that drugs with a different mechanism of action showed some effects in 5-FUinduced intestinal mucositis.

\section{Conclusion}

From this review, it was possible to recognize a considerable number of studies involving intestinal mucositis. The information gathered demonstrates that substances isolated from plants, probiotics with emphasis on those of the genus Lactobacillus, nutritional supplements, and even repurposed drugs were evaluated in connection with 5-FU-induced intestinal mucositis, and these showed a protective effect on several morphological parameters (Figure 2). However, no results were observed with research with humans. Thus, although there are many studies, the treatment of intestinal mucositis remains a gap in science and there is a need for future research with clinical evaluation on the subject.

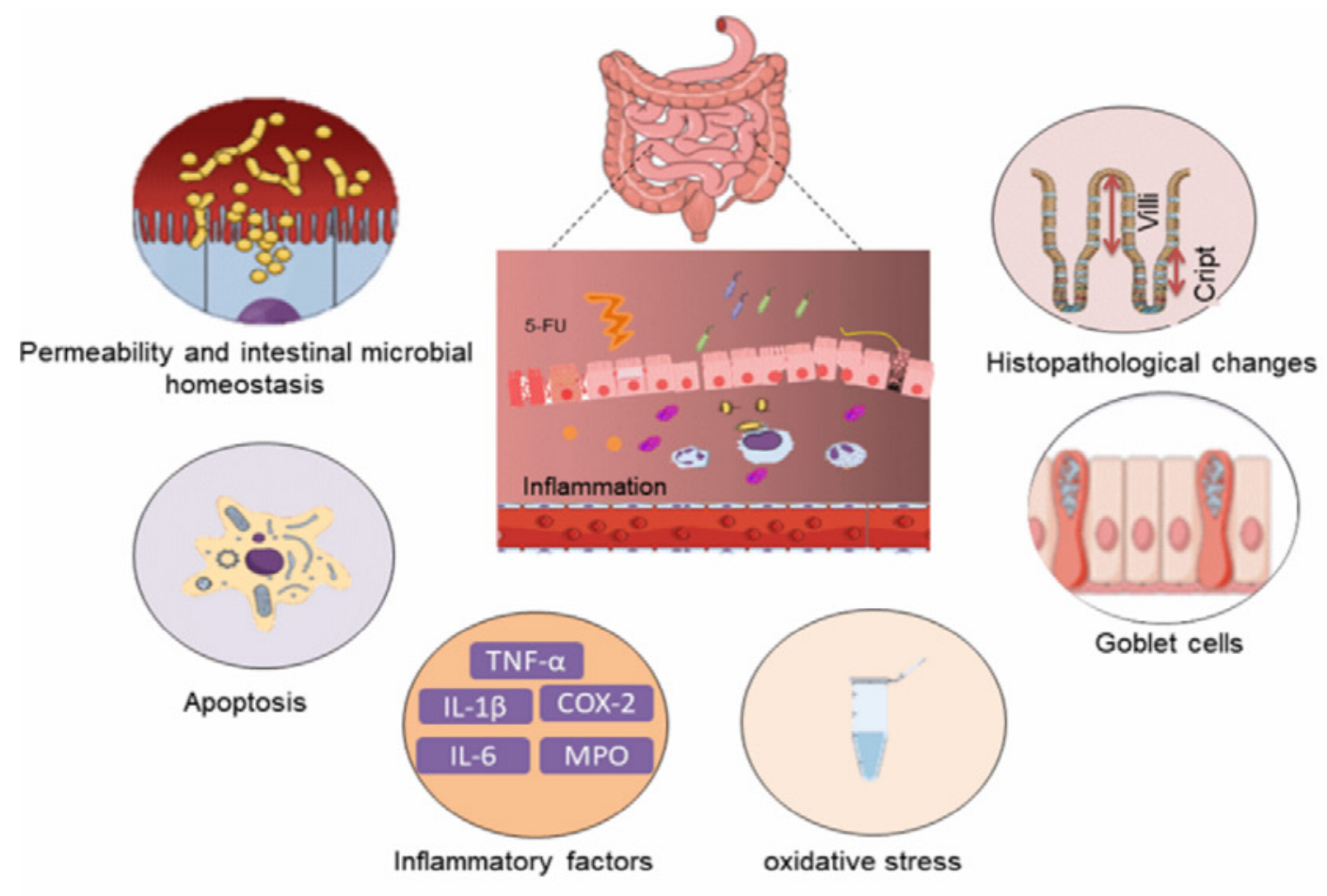

Figure 2. Main parameters evaluated in intestinal mucositis induced for 5-FU. 


\section{References}

1. Atiq, A et al. Diadzein ameliorates 5-fluorouracil-induced intestinal mucositis by suppressing oxidative stress and inflammatory mediators in rodents. European Journal of Pharmacology 2019; 843:292-306.

2. Bajic, JE et al. Rhubarb extract partially improves mucosal integrity in chemotherapy-induced intestinal mucositis. World J Gastroenterol 2016; 22(37): 8322-8333

3. Bastos, RW et al. Saccharomyces cerevisiae UFMG A-905 treatment reduces intestinal damage in a murine model of irinotecan-induced mucositis. Beneficial Microbes, 2016; 2(5):110.

4. Cai, B et al. Protective Effects of Enteral Nutrition Supplemented with Crassostrea hongkongensis Polysaccharides Against 5-Fluorouracil-Induced Intestinal Mucosal Damage in Rats. Journal of Medicinal Food 2018; 21 (4):348-355

5. Ciobanu, L et al. Rifaximin modulates 5-fluorouracil-induced gastrointestinal mucositis in rats. European Review for Medical and Pharmacological Sciences 2016; 20: 4993-5001.

6. Chen, $Y$ et al. Protective effect and potential mechanisms of Wei-Chang-An pill on high-dose 5-fluorouracil-induced intestinal mucositis in mice. Journal of Ethnopharmacology, 2016; 190: 200211.

7. Cordeiro, BF et al. Whey Protein Isolate-Supplemented Beverage, Fermented by Lactobacillus casei BL23 and Propionibacterium freudenreichii 138, in the Prevention of Mucositis in Mice. Frontiers in microbiology 2018; 9:2035

8. Costa, DVS et al. 5-Fluorouracil Induces Enteric Neuron Death and Glial Activation During Intestinal Mucositis via a S100BRAGE-NFkB-Dependent Pathway. Scientific Reports 2019; 9(1):665. 9. De Ávila, PHM et al. Mucoadhesive formulation of Bidens pilosa L. (Asteraceae) reduces intestinal injury from 5-fluorouracilinduced mucositis in mice. Toxicology Reports 2015; 2:563-573 10. De Jesus, LCL et al. Protective effect of Lactobacillus delbrueckii subsp. Lactis CIDCA 133 in a model of 5 FluorouracilInduced intestinal mucositis. Journal of Functional Foods 2019; 53:197-207

11. De Miranda, JAL et al. Protective Effect of Cashew Gum (Anacardium occidentale L.) on 5-Fluorouracil-Induced Intestinal Mucositis. Pharmaceuticals 2019; 12(2): 51

12. De Miranda, JAL et al. Troxerutin prevents 5-fluorouracil induced morphological changes in the intestinal mucosa: Role of cyclooxygenase-2 pathway, Pharmaceuticals. 2020; 13(10).

13. Yeung, cYet al. Amelioration of Chemotherapy-Induced Intestinal Mucositis by Orally Administered Probiotics in a Mouse Model. PloS one, 2015;10(9): e0138746, 2015.

14. Kato $S$ et al. Saireito (TJ-114), a Japanese traditional herbal medicine, reduces 5 -fluorouracil-induced intestinal mucositis in mice by inhibiting cytokine-mediated apoptosis in intestinal crypt cells. PLoS One. 2015; 7;10(1):e0116213.

15. Kim HJ, Moon W, Park J, Park SJ, Song GA, Han SH, Lee JH (2015) Rebamipide Attenuates 5-Fluorouracil-Induced Small Intestinal Mucositis in a Mouse Model. Biological and Pharmaceutical Bulletin 38(2)179-183

16. Generoso, S DE V et al. Dietary supplementation with omega-3 fatty acid attenuates 5 -fluorouracil induced mucositis in mice. Lipids in Health and Disease 2015; 14(1):54

17. Gou, $\mathrm{H}$ et al. Protective effect of Bu-Zhong-Yi-Qi decoction, the water extract of Chinese traditional herbal medicine, on 5-fluorouracil-induced intestinal mucositis in mice. Hum Exp Toxicol 2016; 1243-1251

18. Santos-Filho EX et al. Curcuminoids from Curcuma longaL. reduced intestinal mucositis induced by 5 -fluorouracil in mice: Bioadhesive, proliferative, anti-inflammatory and antioxidant effects. Toxicology Reports 2016; 3:55-62.
19. Bastos, CCC et al. Use of Bidens pilosa L. (Asteraceae) and Curcuma longa L. (Zingiberaceae) to treat intestinal mucositis in mice: Toxico-pharmacological evaluations. Toxicol Rep 2015; 30;3:279-287.

20. Song $M$ et al. Wheat bran arabinoxylan supplementation alleviates 5-fluorouracil induced mucositis and myelosuppression in BALB/c mice. Journal of Functional Foods 2016; 21: 312-320.

21. Kato, $\mathrm{S}$ et al. Probiotic Bifidobacterium bifidum G9-1 attenuates 5-fluorouracil-induced intestinal mucositis in mice via suppression of dysbiosis-related secondary inflammatory responses. Clinical and Experimental Pharmacology and Physiology 2017; 44(10):1017-1025

22. Sano $\mathrm{T}$ et al. Lafutidine, a histamine $\mathrm{H} 2$ receptor antagonist with mucosal protective properties, attenuates 5-fluorouracilinduced intestinal mucositis in mice through activation of extrinsic primary afferent neurons. Journal of physiology and pharmacology 2017; 68 (1):79-90

23. Zhang, $T$ et al. Volatile oil from Amomi Fructus attenuates 5 -fluorouracil-induced intestinal mucositis. Frontiers in Pharmacology 2017; 8:786

24. Tang, $Y$ et al (2017) Administration of probiotic mixture DM\#1 ameliorated 5-fluorouracil-induced intestinal mucositis and dysbiosis in rats. Nutrition, 33:96-104

25. Oh, NS et al (2017) Mulberry leaf extract fermented with Lactobacillus acidophilus A4 ameliorates 5-fluorouracil-induced intestinal mucositis in rats. Letters in Applied Microbiology 64(6):459-468

26. Levit, $R$ et al (2018) Protective effect of the riboflavinoverproducing strain Lactobacillus plantarum CRL2130 on intestinal mucositis in mice. Nutrition 54:165-172

27. Medeiros, A DA C et al. Effects of simvastatin on 5-fluorouracilinduced gastrointestinal mucositis in rats. Rev. Col. Bras. Cir.2018;.45. (5).

28. Galdino, FMP et al. Pretreatment and treatment with fructooligosaccharides attenuate intestinal mucositis induced by 5-FU in mice. Journal of Functional Foods 2018; 49:485-492

29. Zheng, $\mathrm{H}$ et al (2019) The protective effects of Aquilariae Lignum Resinatum extract on 5-Fuorouracil-induced intestinal mucositis in mice. Phytomedicine 54:308-317

30. Wang, C.; Yang S.; Gao, L; Wang,L; Cao, L. Carboxymethyl pachyman (CMP) reduces intestinal mucositis and regulates the intestinal microflora in 5-fluorouracil-treated CT26 tumourbearing mice. Food and function 2018; 9, 2695.

31. Huang, L et al. SCID/NOD mice model for 5-FU induced intestinal mucositis: Safety and effects of probiotics as therapy. Pediatrics and neonatology 2019; 60: 252-260.

32. Fidelis LS et al. Role of Rutin in 5-Fluorouracil-Induced Intestinal Mucositis: Prevention of Histological Damage and Reduction of Inflammation and Oxidative Stress. Molecules 2020; 25:2786.

33. Xiang DC et al. Protective effect of Andrographolide on 5-Fu induced intestinal mucositis by regulating p38 MAPK signaling pathway. Life Sci, 2020 1:117612.

34. Chen $\mathrm{H}$ et al. Berberine regulates fecal metabolites to ameliorate 5-fluorouracil induced intestinal mucositis through modulating gut microbiota. Biomedicine \& pharmacotherapy 2020; 124:109829.

35. Carvalho PLA et al. Prophylactic and therapeutic supplementation using fructo-oligosaccharide improves the intestinal homeostasis after mucositis induced by 5-fluorouracil. Biomedicine \& Phamacotherapy 2021; 133:111012.

36. Van Vliet MJ, Harmsen HJ, de Bont ES, Tissing WJ (2010) The role of intestinal microbiota in the development and severity of chemotherapy-induced mucositis. PLoS Pathog 6:e1000879. 


\section{Mini Curriculum and Author's Contribution}

1. Maria Lucianny Lima Barbosa -MsC; PhD student. Contribution: Effective scientific and intellectual participation for the study; data acquisition; data interpretation; preparation and draft of the manuscript; critical review and final approval. ORCID: 0000-0003-1652-6544.

2. Lorena Lopes Brito-Miss. Nutrition student; Contribution: Data acquisition; data interpretation; preparation and draft of the manuscript. ORCID: 0000-0001-6313-1794.

3. Bárbara Barbosa Pires-Miss. Medical student; Contribution: Data acquisition; data interpretation; preparation and draft of the manuscript. ORCID: 0000-0003-2269-0690

4. Joselane Maria da Silva-B.Sc. Nutritionist; Contribution: Data acquisition; data interpretation; preparation and draft of the manuscript. ORCID: 0000-0002-1111-659X

5. João Antônio Leal de Miranda; PhD. Contribution: Effective scientific and intellectual participation for the study; critical review and final approval.

ORCID: 0000-0002-0273-4169

6. Gilberto Santos Cerqueira; PhD. Contribution: Guiding professor; Design of the study; critical review and final approval. ORCID: 0000-0001-6717-3772

Received: April 19, 2021

Accepted: April 30, 2021
Corresponding author

Maria Lucianny Lima Barbosa

E-mail: lucianny.barbosa@alu.ufc.br 